\title{
Stigmatizáció és időskori mentális betegségek
}

\section{Vajsz Kornél - Horváth Márton - Simon Lajos - Vass Edit - Sztancsik Veronika}

\author{
VAJSz KoRnéL: Debreceni Egyetem Bölcsészettudományi Kar Pszichológiai Intézet - \\ kornel.vajsz@gmail.com \\ HoRvÁTH MÁRTON: Semmelweis Egyetem Általános Orvostudomány Kar - \\ horvath.marton95@gmail.com \\ SIMON LaJOs: Moravcsik Alapítvány; Semmelweis Egyetem Pszichiátriai és Pszichoterápiás \\ Klinika - simon.lajos@med.semmelweis-univ.hu \\ VASs EDIT: Semmelweis Egyetem Pszichiátriai és Pszichoterápiás Klinika - vass.edit84@gmail.com \\ SzTANCSIK VeroniKa: Debreceni Egyetem Klinikai Központ, Felnőtt Pszichiátriai Osztály - \\ sztancsik.veronika@kenezy.unideb.hu
}

\begin{abstract}
ABSZTRAKT A tanulmány célja az időskori mentális betegségekre vonatkozó társadalmi és személyes megbélyegzések jelentőségének bemutatása. A mentális betegséghez kapcsolódó stigma-fogalmak és jelenségek bemutatásán túl bevezető ismereteket nyújt abba, milyen pszichés problémákkal járhat az idősödés, hogyan alakul a saját mentális nehézségekhez való viszony idős korban, és erre milyen hatással lehet a társadalmi nyomás, amit stigmának, megbélyegzésnek nevezünk. Felhívja a figyelmet arra, milyen ártalmas hatása lehet mind az időskor, mind a mentális betegségek megbélyegzésének a felismerés, a prevenció és a kezelés szempontjából. A tanulmány zárásaként bemutatkozik a szerzők részvételével szerveződött antistigma kutatócsoportunk, mely a mentális betegségek stigmatizációjának csökkentése mellett köteleződött el.
\end{abstract}

Kulcsszavak: stigma, idős kor, mentális betegségek

\section{Stigmatization and mental illness of the elderly}

ABSTRACT The aim of this paper is to present the significance of social and personal stigma associated with mental illness in old age. In addition to introducing the concepts and notions of stigma associated with mental illness, it provides preliminary insights into the psychological problems of aging, the relation to one's own mental difficulties in old age, and the social pressures of stigmatization. It draws attention to the detrimental effects that stigma associated with old age and mental illness can have on the recognition, prevention and treatment of the latter. Finally, the National Antistigma Programme (NAP) research group is presented, which is organized with the participation of the authors and is committed to reducing the stigma of mental illness.

Keywords: stigma, old age, mental illness 


\title{
BEVEZETÉS: AZ IDÖS KOR KIHÍVÁSAI
}

\author{
„Oly árvák ők mind, az öregek. \\ Az ablakból néha elnézem őket, \\ hogy vacogó szélben, gallyal hátukon \\ mint cipekednek hazafelé - \\ vagy tikkadt nyárban, a tornácon \\ hogy üldögélnek a napsugárban - \\ vagy téli estén, kályha mellett \\ hogyan alusznak jóizüen - \\ nyujtott tenyérrel a templom elött \\ úgy állnak búsan, csüggeteg, \\ mint hervadt őszi levelek \\ a sárga porban."
}

(Weöres 1975: 13)

A 15 éves Weöres Sándor szavai érzékletesen vázolják a korosodó emberek képét a külső szemlélő nézőpontjából. Talán már valamennyien találkoztunk ehhez hasonló vagy romantikusabb elképzeléssel, mely szerint az öregkor a csendes, elmélyült bölcsesség időszaka, ahol a tapasztalatok megérnek és a múlt tanulságaitól gazdag ember számot vet sorsának mélységével. Ezen látásmódokra leginkább a jóindulatú távolságtartás jellemző. Valójában, amiképp a többi életszakaszt, úgy az időskori változásokat is biológiai faktorok alapozzák meg, aminek megélése egyénenként különbözhet. A test, ahogy a lélek is, megannyi küzdelem, megpróbáltatás nyomát viselheti magán. Bizonyos terhek súlya alól nem szabadulhatunk: legyenek azok társadalmi, élettani vagy pszichológiai jellegüek. Mai ismeretek szerint betegség hiányában akár 120-130 évig is élhetnénk, viszont csak a legritkább esetben közelítjük meg azt (Semsei 2014).

Tanulmánykötetében Tariska ekképp jellemzi az időskorral kapcsolatos mai attitűdöket: „A közgondolkodásban - sokszor még az orvosokéban is - az időskor és a testi-lelki sorvadás sokszor szinonimák, a terápiát reménytelennek, a diagnosztikát éppen ezért sokan akadémikusnak, a beteget feleslegesen terhelönek tartják." (Tariska 2002: 27)

Ahogyan az ember társadalmi lényként éli életét, ez az időskorban sincsen másképp: a szociokulturális háttér befolyásolja az idősödés folyamatát. Mást jelent korosodónak lenni egy olyan közösségben, ahol minden dolgos kézre szükség van, ahol az erőforrások szükösek, és mást egy nyugodtabb életet megengedő, lassúbb folyású miliőben. Ez még persze nem határozza meg teljesen, hogyan gondolkodik majd az öregkorról ember és környezete. A megélés minősége sokkal bonyolultabb képletből ered: az egyén saját testi, intellektuális, érzelmi tapasztalataival kezdődik, a társas közegből adott visszajelzésekkel folytatódik, majd újrakezdődik azzal, ahogyan ezek a visszajelzések reflektálódnak. A kép, melyet a személy magáról, közegéről és saját helyéről ebben a közegben megalkot, a fent említett valamennyi jelenség által formálódik (Combs - Snygg 1959, Pethő 1989).

Az öregségről alkotott képet tovább árnyalja annak belső ellentmondásossága. $M i$ is az öregség? Vajon bölcs aranykor, esetleg sorvadó hanyatlás? Ilyen és ehhez hasonló vélemények egyszerre létezhetnek valamennyi személyben, legyen ifjú vagy agg. A hanyatlás képét megerősítheti a késztetések perzisztenciája a test elkerülhetetlen kimerülésével szemben (pl. a fizikai aktivitás vagy a nemiség tekintetében). Időskorban az ember nem csak azzal néz szembe, hogy élete egyszer véget ér, hanem azzal is, hogy az odavezető úton fizikai és nem ritkán mentális erőforrásai kiapadnak (Pethő 1989). A késői években több kihívással kell az egyénnek 
szembenézni. Nem csak a rövidülő idő, hanem a vitalitáscsökkenés véglegessége is beárnyékolja életét. Sokan ennek nyomása alatt inkább a múltba kapaszkodva őrzik azt a képet, akik egykoron voltak. Kevésbé jellemző, hogy aggkori énjük felé ifjonti nyitottsággal forduljanak, megváltoztatva énképüket, elfogadva a változásokat, ami szervezetükben lezajlik (Tariska 2002).

Erikson (2002) eredeti fejlődéselméletében a személyiség érésének utolsó lépcsőfoka az „integritás megteremtése a kétségbeeséssel szemben”. Ekkorra valamennyi személyiségfejlődési szakasz kérdése újra felmerül: a bizalom, autonómia, kezdeményezés, teljesítmény, identitás, intimitás és alkotóképesség kérdései. Ezek összegződnek abban a kérdésben, hogy vajon jól élte-e az ember az életét, amikor már nem sokat tud változtatni rajta. Mindezek tükrében az egészséges idős ember számára is komoly lelki munkát jelenthet az önmagával való hü szembenézés. Emellett különösen megerőltető lehet egy-egy gyengeséggel, vagy újkeletű problémával találkozni. Cikkünk azt kívánja bemutatni, milyen pszichológiai problémákkal járhat az idősödés, hogyan jelenik meg a saját mentális nehézségekhez való viszony idős korban, és erre milyen hatással lehet a társadalmi nyomás, amit stigmának, megbélyegzésnek nevezünk.

\section{IDÖSKOR EURÓPÁBAN ÉS MAGYARORSZÁGON}

Az Európai Unió népességének 20,3\%-a 65 év feletti, ez a tíz évvel korábbi adathoz képest 2,9 százalékpontos növekedést jelent (Eurostat 2020). Magyarország e tekintetben az uniós átlagnak megfelelő eredményekkel bír. A Központi Statisztikai Hivatal (2020) legfrissebb adatai szerint Magyarország öregedési indexe 136,6 fö, azaz 10014 éves vagy fiatalabb emberre 136,6 65 éves vagy annál idősebb személy jut. Ez az érték 1990-ben még 65 volt, 2017-ben pedig 129. Egyre növekszik 65 éves korban várható élettartam is: a férfiak esetében ez 14,4, a nőknél 18,2 év, nagyjából 120\%-os növekedést mutatva 1990-hez képest. A 65 év felettiek hátralevő életéveiknek csupán 30-40\%-át töltik egészségesen (Monostori - Gresits 2018). Ezt erősíti meg az Eurostat (2019) statisztikája is, miszerint a magyar 65 év felettiek 60\%-a számol be nehézségekről az önellátás és háztartásvezetés terén.

A társadalom rohamos elöregedésével az időskor kérdései egyre nagyobb jelentőséggel bírnak, közülük is kiemelkedik a mentális betegségek problematikája. A World Health Organization (2020) adatai szerint az Alzheimer-kór és egyéb demenciák már a hetedik helyen állnak a világ leggyakoribb halálokai között, a magas jövedelmű országokban - így Magyarországon is - pedig már a második helyet foglalják el.

\section{A LEGFONTOSABB GERONTOPSZICHIÁTRIAI KÓRKÉPEK}

Időskorra a szervezetnek számos biológiai, illetve pszichoszociális változással kell szembenéznie, amelyek hozzájárulnak a mentális egészség megromlásához (Tringer 2010). A biológiai tényezők közül különösen fontos a testi betegségek fennállása. A szív- és érrendszeri betegségekben szenvedő idősek 15-40, de akár 60\%-a is szenved depresszióban, illetve a depresszió is többszörösére növeli a keringési betegségek kockázatát (Zhang et al. 2018). Pszichoszociális szempontból kiemelendő, hogy az időseknek kortársaik, barátaik elhunytával egyre több 
veszteséggel kell megbirkózniuk, nyugdíjba vonulásukkal pedig nem csak szociális kapcsolataik szűkülnek be, de gazdasági helyzetük is romlik. A modern nyugati társadalom családmodellje pedig a családi kapcsolatok lazulásával is fenyegeti az időseket.

A leggyakoribb időskori pszichiátriai kórképek a demencia, depresszió és delírium. Az időskori depresszió prevalenciája 5-10\% körülire tehető, és a demenciával való komorbiditása is igen magas (Tringer 2010). A befejezett öngyilkosságok száma is növekszik az életkorral, de idős korban az öngyilkos gondolatok is gyakrabban jelennek meg. A befejezett öngyilkosság fontos rizikófaktora a depressziós hangulatzavar, a testi betegségek, az izoláció, és az időskori gyógyszerszedés miatt kéznél levő, túladagolható altatók és fájdalomcsillapítók (Vörös 2010). Az időskori depresszió felismerését megnehezíti annak tünetszegény volta. A hangulatzavart jellemzően csak egy-két tünet jelzi, melyek sokszor testi betegség, vagy értelmi hanyatlás (pszeudodemencia) formáját öltik.

A demencia előfordulása szintén 10\% körüli a 65 év feletti népességben, és gyakorisága az életkor előrehaladtával nő. Az időskori demenciák legnagyobb része az Alzheimer-kór számlájára írható, a második helyen pedig az éreredetű (vaszkuláris) demencia áll, azonban a kevert típus is nagyon elterjedt.

A delírium, avagy tudatborult állapot mindig másodlagos jelenség valamely organikus zavar, azaz testi, biológiai állapot talaján. Delíriumban a tudat integritása felborul, az éberség jelentősen fluktuál, a beteg tér- és időbeli orientációja elvész, hallucinációk, gondolkodási zavarok és pszichomotoros eltérések jelentkeznek.

\section{IDŐSKORI MENTÁLIS PROBLÉMÁK FELISMERÉSE A GYAKORLATBAN}

Ólafsdóttir et al. (2001) egy svéd város alapellátását vizsgálva mutatták ki, hogy az időskori mentális betegségeknek diagnosztikájára nincs felkészülve az ellátórendszer. Összesen 350, háziorvoshoz forduló, 70 éves kort betöltött személyt vizsgáltak. Mindösszesen $6 \%$ fordult mentális problémával a háziorvoshoz. Az érkező személyek egyharmadánál mutattak ki szakorvosok különböző pszichiátriai betegségeket. A dokumentált esetek száma ezzel szemben $26 \%$ volt - a páciensek egyötöde tehát nem pszichológiai panasz miatt jelent meg, pedig gondjai pszichológiai jellegüek voltak. A szakorvosok által kimutatott zavarok fele demencia (16\%), a másik fele (17\%) elsősorban depresszív (12\%) és szorongásos (11\%) zavarokból állt. (A zavarok egy része között komorbiditás áll fenn: egyszerre vannak jelen.) Érdekes adalékot nyújtanak a vizsgálatban résztvevő páciensek kartonjainak számadatai. Ezeket háziorvosok írták, és míg a demencia (4\%) és a depresszió (6\%) lényegesen alacsonyabb volt, mint a pszichiáterek által felvett vizsgálatokban, a problémák nagy részét az alvászavarok adták (21\%). Ez azt jelenti, hogy a mintában csak minden negyedik demenciában, és minden második depresszióban szenvedő ember problémájára derült fény az orvosi alapellátásban. A szerzők szerint ezt három ok magyarázza: (1) Az emberek szomatikus problémákkal fordulnak háziorvoshoz, ami eredményezheti, hogy a háziorvos már csak a szomatizált problémával találkozik, melynek pszichés gyökerei vannak (Goldberg - Bridges 1988). (2) Az egyes háziorvosoknak sokkal kevesebb ideje van foglalkozni a páciensekkel, mint amennyi egy pszichiátriai diagnózishoz szükséges. (3) Azoknak is lehetnek lelki nehézségei, akik nem rendelkeznek mentális zavarral. Ilyen tünetből meglehetősen sok lehet, a háziorvosnak pedig nem könnyü átlátni 
azokat. Szaktudás nélkül nehéz elkülöníteni az érzelmek adekvát elváltozását egy nehéz helyzetben a konkrét mentális zavartól. Ez a többi zavarral szemben könnyen azonosítható alvászavarok prevalenciáját is magyarázhatja. Emellett sok páciens, még ha nem is rendelkezik egy mentális zavar kritériumainak megfelelő elegendő tünettel, pszichológiai kezelésre szorulhat (Weiller et al 1998, Williams et al. 1995). Ólafsdóttir et al. (2001) azt találták, hogy ahol diagnosztizálták a pszichés zavart, azt többnyire gyógyszeresen kezelték is a háziorvosok. A kutatás eredményei szerint tehát nem a kezelésben, hanem inkább a pszichiátriai problémák felismerésében, diagnosztikájában mutatkoztak hiányosságok.

Ólafsdóttir és munkatársai kutatási eredményeit megerősítették Andreas et al. (2014) is. A felmérésben a Composite International Diagnostic Interview (CIDI, Összetett Nemzetközi Diagnosztikus Interjú) 65 feletti korosztályhoz igazított változatát használták mérőeszközként. A reprezentatív 3142 fős nyugat-európai minta vizsgálata során kimutatták, a 65 és 84 közötti korban minden harmadik személy szenvedett a megelőző egy évben valamilyen mentális zavarban, ami minden negyedik személynél a kutatás ideje alatt is fennállt. Az új vizsgálat megerősítette a szorongásos zavarban szenvedők arányát $(11,4 \%)$, továbbá a hangulatzavarban szenvedőkét 8,0\%-ban, és a szerhasználatból eredő zavarokat 4,6\%-ban állapította meg. A vizsgálat epidemiológiai részében megerősítették, hogy az ismétlődő depressziós zavar kétszer, az agorafóbia hétszer, az alkoholizmus másfélszer gyakrabban fordul elő időskorban, mint a 65 év alatti személyeknél.

Egy 2005-ös magyar, a Szent László Kórház Konzultációs Pszichiátriai Osztályának beteganyagán végzett statisztikai elemzés szerint a gerontopszichiátriai konzultációk harmada affektív zavarra utaló tünetegyüttes, 28\%-a demencia, 8,8\%-a delírium miatt történt. Ezen föbb betegségek mellett az időskorra jellemzőek még a szorongásos és szomatoform zavarok, illetve a szerhasználattal összefüggő kórképek is (Gazdag - Sebestyén 2005).

Ezek az eredmények felhívják a figyelmet arra, hogy az időskori mentális betegségek igen gyakoriak, egy részük pedig valószínüen még mindig kezeletlen, rontva az időkorú emberek életminőségét, jóllétét. Feltételezzük, hogy ebben a mentális betegségek stigmatizátsága is szerepet játszik (Sztancsik 2019).

\section{A STIGMA?}

Mindnyájunknak vannak tapasztalataink sztereotípiákról, elfogultságról, és az abból kialakuló megbélyegzésről, a stigmáról. A társas stigmát mint a társadalmi normaszegés következményét először Durkheim (1982) emelte be a tudományos diskurzusba a 19. század végén. Állítása szerint egy „bünmentes” társadalom mindig létrehozza saját bünöseit, akikből „betegeket” is csinálhat. Ami a kívülálló szemével bocsánatos kilengésnek, apró hibának látszik, az a „bűnmentes" társadalomban közfelháborodás és skandalum tárgya lehet. Ez a szubjektív, társas megbélyegzettség az, amit Goffman újra elővett tudományos kutatásai során. Goffman megközelítésében a stigma egy olyan jelző, amely hordozóját annak mentén leértékeli, hitelteleníti, szégyenletessé teszi. Goffman szerint nem is az a kérdés, hogy egy társadalomban stigmatizáltak vagyunk-e, hanem hogy hány szempontból tapasztaljuk azt. Előfordulhat, hogy valaki egy szembetűnő tulajdonság - időskor, testsúly, temperamentum - miatt viseli stigmáját, ahogyan az is, hogy rejtettebb múltja, szokásai, diszpozíciója, egészségi állapota miatt áll pellengé- 
ren. Goffman eredetileg három dimenziót különböztetett meg: a jellemhibákat, melyek erkölcsi gyengeségre utalhatnak, a testi elváltozásokat és a társas másságot. A lehetséges kombinációk száma magas és egy erősebb kitettség esetén a megbélyegzett fél eleshet erőforrásaitól. Az érintett el is szigetelődhet helyzetében, aminek eredményeként megküzdési mechanizmusai „rövidzárlatossá” válhatnak - hisz izolációjában nincs kihez, mihez forduljon - ami súlyos distresszel jár (Goffman 1963, Hatzenbuehler 2009, Hatzenbuehler 2016, Sztancsik 2018, Sztancsik 2019).

\section{AZ IDŐSKOR ÉS A MENTÁLIS BETEGSÉGEK STIGMÁJÁNAK JELLEMZÖI}

Jones et al. (1984) hat dimenzió mentén osztályozták a nemkívánatos jeleket, melyeket deviánsnak ítél a társadalom, és elindíthatják a kirekesztés folyamatát:

1. Esztétikusság, avagy mennyire taszító az emberek számára, azaz milyen hangulati, érzelmi reakciót vált ki belölünk.

2. Elrejthetőség, avagy mennyire szembetünő a megbélyegzett tulajdonság.

3. Lefutás, avagy mennyire végleges az a dolog, ami a megbélyegzés tárgya. Ha visszafordítható, mennyi idő, energia, szerencse szükséges hozzá.

4. Zavaróság, avagy mennyire befolyásolja, akadályozza a megbélyegzettség a társas interakciókat.

5. Eredet, avagy mennyiben felelős a megbélyegzett személy a megbélyegzés tárgyáért.

6. Veszélyesség, avagy mennyiben veszélyezteti az embereket - akár fizikailag, akár pszichésen - a megbélyegzés tárgya. Ha a megbélyegzettel kapcsolatba lépő embert is megbélyegzés fenyegeti, az is ide tartozik.

Az így kapott dimenziókon elindulva a jelenséget annak mélyebb komplexitásában vizsgálták kutatók. Frable et al. (1998), valamint Hatzenbuehler et al. (2009) például megmutatták, hogy az elrejthető bélyeggel rendelkező emberek kevesebb társas támogatáshoz jutottak, jobban elszigetelődtek a segítségtől, összességében alacsonyabb önbecsüléssel rendelkeztek, mint a szembetűnő bélyeggel rendelkezők. Az önbecsülés kérdése nem csak a társadalmi megbélyegzettséggel, de a belsővé tett stigmával is összefüggést mutathat. Corrigan elmélete szerint megkülönböztethetünk nyilvános stigmát és önstigmát. Míg előbbi a nagyobb társadalmi csoport közös negatív sztereotípiáin alapuló bélyeg, utóbbi a nyilvános attitűdök internalizációja, ami gyakran az önbizalom és az énhatékonyság elveszítéséhez vezet, ami elmélyítheti az egyén izolációját (Corrigan et al. 2005, Corrigan - Watson 2002, Pachankis et al. 2018).

A stigma eredet dimenziója és annak megítélése szorosan összefügg a kontrollálhatóság értékelésével. Amennyiben a külső szemlélők a stigma tárgyát kevésbé kontrollálhatónak tartják - mint például a rák, vagy testi fogyatékosság esetében - úgy kevésbé is fordulnak el a megbélyegzettektől, szívesebben segítenek nekik, mint amikor úgy vélik, a személy felelös rossz helyzetéért - mint például HIV-fertőzöttség vagy elhízás esetében (Weiner et al. 1988). Azaz, ha az egyén hatáskörén kívül álló okoknak tulajdonítjuk az állapotot, talán kevésbé izoláljuk a megbélyegzett embert a közösségben. 
Pachankis és munkatársai (2018) kimerítő vizsgálatot állítottak össze a Jones-i dimenziók mentén, 93 stigmatizált állapottal, a dimenziók közötti interakciók és az egészségre, a megküzdésre és más pszichológiai tényezőkre gyakorolt hatások figyelembevételével. A kutatásban szakértők és avatatlan laikusok vizsgálati mintája értékelte az összegyüjtött stigmatizált állapotokat az egyes dimenziók mentén, illetve ezt egészítették ki egy távolságtartás pontszámmal is, ami arra kereste a választ, hogy a köz embere - maga a kitöltő - vajon mekkora távolságot tartana a stigmával rendelkező személytől.

A stigmatizált állapotoknál szerepelt többek között az időskor, mentális betegségek, szokatlan megjelenés vagy szexuális irányultság stb. is. Az időskorról megállapították, hogy míg a lefutás dimenzió legmagasabb értékét érte el - mint végleges, visszafordíthatatlan állapot addig az elrejthetöség, a veszélyesség, és az eredet dimenziók mentén az utolsók között volt, vagyis szembeszökő volt, veszélytelen és elkerülhetetlen. A zavaróság és az esztétikusság dimenziók mentén azonban az első harmadban voltak az „időskor” értékei a többi stigmához képest. Első pillantásra ez talán nem is tünik olyan rossznak, de fanyarul árnyalja a képet, hogy a zavaróság mentén két szomszédja a „HIV-fertőzés” és a „kétneműség”, az esztétikusság mentén pedig a „bipoláris zavar aktív tünetei” és a „széttetovált test” voltak. A kutatás mérései szerint e dimenziók magas értékei fokozott távolságtartással járnak, tehát a külső szemlélők hasonlóan kerülik az időseket, a HIV-fertőzötteket és a kétneműeket a zavaróság mentén. Az alacsony esztétikusság mentén pedig a bipoláris problémában szenvedőket és a sok, látható tetoválással rendelkezőket kerülik az idősekhez leginkább hasonlatos mértékben. Erre a vizsgálatra épülő másik kutatásuk eredménye szerint a zavaróság az egyedüli stigma-változó, ami szignifikáns valószínűséggel korrelál negatívan az egészségi állapot mutatóival az érintetteknél és a stresszel való megküzdéssel is. Összefoglalva, az idős kor stigmája olyan jellemzőkkel rendelkezik, amik a külső szemlélőt távolságtartásra késztethetik és a stresszel való hatékony megküzdést, az egészségi állapotot is negatívan befolyásolják az érintetteknél (Pachankis et al. 2018).

Ami a mentális betegségeket illeti, a fent idézett vizsgálat szerint az egyes mentális betegségek stigma-jellemzői más-más tartalmat mutatnak a Jones-i dimenziók mentén. Például más értékeket kap a hat faktorban a mentális retardáció, mint a szkizofrénia, a bipoláris zavar vagy éppen a depresszió. A stigma-tulajdonságok közül a tartós lefutás, a zavaróság és a veszélyesség függnek össze legszorosabban az érintettek rosszabb egészségmutatóival, és ezek azok a tulajdonságok, amiknél legerősebb stigmatizáltságot észlelnek az érintettek is. Ezekben a tulajdonságokban magasabbra értékelt mentális betegségek esetén van kitéve a pszichés betegséggel küzdő ember leginkább a stigma jóllétet rontó hatásának is. A nagyobb társas távolságtartásban mindezek közül kulcsszerepet játszik a veszélyesség megítélése. Akiket a közgondolkodás „veszélyesnek” tart, azok az emberek vannak leginkábbb kitéve az izolálódás, elmagányosodás veszélyének is. Ezen a dimenzión az egyik legmagasabb értéket a szkizofréniával élők kapják - holott javarészt nem veszélyesebb emberek, mint mások és fokozott társas támogatásra lehet szükségük (Pachankis et al. 2018, Sztancsik 2018, Sztancsik 2019).

Amikor az időskori mentális betegségekhez füződő megbélyegzésről gondolkodunk, fontos szempont lehet, hogy ezek esetén egyszerre van jelen az éppen adott mentális betegség és az időskor stigmája. Mindez szerepet játszhat abban is, hogy az időskorú és mentális betegséggel élő emberek jelentős része elmagányosodik, nem kap megfelelő pszichiátriai, pszichológiai segítséget (I. korábban is). 


\section{HOGYAN ALAKUL KI A STIGMA?}

Két évtized stigmakutatás eredményeként Link és Phelan kezdtek el foglalkozni a kirekesztett személy belső élményvilágával. A megbélyegzés folyamatainak leírása során összesen öt jellemzőt állapítottak meg, melyek közül valamennyi kölcsönösen áthatja egymást és szükséges a stigmatizáció kialakulásához. Ilyen a címkézés, avagy egy nemkívánatos tulajdonság kiemelése, megjelölése. Ezzel tulajdonképpen az emberek merev kategóriákat készítenek az adott jelző mentén, melybe valaki vagy beletartozik, vagy nem. A sztereotipizálás, avagy a kategória további tulajdonságokat, jellemzően negatív attribúciókat von maga után. Az elkülönítés során a „mi” és az „ők” élesen kettéválik: a nemkívánatos tulajdonság most már nem csak kategória, de külső embercsoporthoz tartozik, melynek valaki vagy tagja, vagy nem. A következő lépés a státuszvesztés, ahol a személyt azonosítják az elkülönített csoporttal és ezáltal rangjától elesik. Végül a diszkrimináció az, amikor a kirekesztettségből származó konkrét hátrányokat saját bőrén tapasztalja (Link - Phelan 2001, Sztancsik 2018, Sztancsik - Szemán-Nagy 2020a).

A megbélyegzés nem feltétlenül áll meg a közvetlen érintetteknél. Mentális problémák esetén például a felépülőben lévő és gyógyult személyek is magukon hordhatják a stigmát, ahogyan a hozzátartozók, családtagok, közeli barátok, sőt a kezelő személyzet is megbélyegzett lehet (Sztancsik 2019).

Minden ember, aki megöregszik, nagy valószínüséggel ismerője az öregséggel kapcsolatos társadalmi sztereotípiáknak. Az időskor közeledtével azonosulhat szerepével, leépítheti fiatalos szokásait, terveit, mondván, nincs már sok hátra. Mások - kivált, ha betegségnélküliek, és emiatt a testi változás kevésbé hangsúlyos számukra - inkább belső korukkal azonosulnak. Előbbi esetben az egyén megfelel a társadalmi sztereotípiáknak, míg utóbbi esetben az identifikációs disszonancia szakadatlan feloldása kötheti le az energiákat. Frusztrációs helyzetek sora hozza el az óhatatlan szembenézést a valódi életkorral (Pethő 1989).

Link és Phelan elsősorban a nyilvános stigmák szemszögéből közelítették meg a kialakulás folyamatát. Az önstigmák, mint korábban láttuk a nyilvános stigmák belsővé tételéből származnak. Amit a társadalom gondol „róluk”, az a belsővé tett stigma esetén ezentúl „én vagyok”, tehát „én” is olyan vagyok, mint „ök”. Megbélyegzettség esetén mindez az önbecsülés, az önértékelés és az én-hatékonyság érzésének csorbulásával jár (Corrigan et al. 2005).

Corrigan és Watson az önstigma kialakulását a mentális zavarok esetén egy négylépcsős folyamatként írja le. Első lépéseként tudatosulnak a mentális betegségekkel kapcsolatos hozzáférhető, nyilvános sztereotípiák. Második lépésben az érintettek maguk is elfogadják a kérdéses sztereotípiákat, egyetértenek velük. Harmadik lépésben kezdik ezeket önmagukra is alkalmazni, azonosulnak, elhiszik magukról a sugallt képet. Negyedik lépésben pedig az önbecsülés sérülése is bekövetkezik (Corrigan - Watson 2002, Sztancsik 2019).

A mentális betegséghez füződő stigma kutatói három, az érintett perspektívájából vizsgált stigma-összetevőt különböztetnek meg, ami valamennyi folyamatban érvényesül. Ilyen az észlelt stigma, az elöítélet, avagy az abba vetett hit, hogy a társadalom negatívan viszonyul az érintett állapothoz, anélkül hogy az embert teljességében látnák. Ilyenkor a megbélyegzett személy úgy véli, egyéni tulajdonságait nem veszik figyelembe, elhalványulnak a stigmatizált állapot mellett. Ilyen továbbá a tapasztalt stigma, a diszkrimináció, avagy azon konkrét esetek, amikor hátrányos megkülönböztetést él át az érintett. Ezek lehetnek elszigetelt esetek, de ala- 
pulhatnak szokásokon, sőt magán a jogrendszeren is. Fontos megjegyezni, hogy az észlelt stigma nem mindig vezet tettleges diszkriminációhoz, de ha mégis, akkor ennek eredményeként a kirekesztett alacsonyabb pozícióba kerül, jogai kevésbé érvényesülnek, lehetőségei megfogyatkoznak. Ilyen végül az önstigma is, amikor az egyén önmaga válik saját megbélyegzőjévé (I. korábban) (Corrigan - Watson 2002, Sztancsik 2019, Thornicroft 2006, Yanos et al. 2008).

\section{MIÉRT ALAKUL KI A STIGMA?}

A stigmát mindig megelőzi a negatív sztereotip attribúció. Egy rossz vélekedés azonban még nem okoz rendszerszintü kirekesztést, ahhoz bonyolultabb folyamatok szükségesek. A stigmák kialakulásának kérdésére többféle magyarázat született: Corrigan és munkatársai három kölcsönösen összefüggő modellt írtak le, ami szociális kognitív, motivációs, és szociológiai szempontok szerint foglalja össze a megbélyegzés eredetét.

A szociális kognitív modellek szerint a sztereotipizálás a gyors és felületes tájékozódási folyamatok szükségességével magyarázható. Nem minden esetben van lehetősége, elégséges erőforrása az egyénnek, hogy mélységében fontolhatná meg környezetének valamennyi elemét. Az egyszerüsített feldolgozás mögött a helyzetek uralásának vágya, vagy a kapcsolódás igénye is lehet a világot hasonlóan látó személyekkel (Corrigan et al. 2005, Smith et al. 2016, Sztancsik 2019). Ebböl és a klasszikus kondicionálás, a társas tanulás és az önészlelés kölcsönös hatásaiból épülnek fel attribúcióink. Eszerint, ha valaki gyakran észleli, hogy mások vagy ő maga idegesebb, szorongóbb egy „mentális problémával” felcímkézett személy társaságában, akkor ez az állapot assszociálódik a címkéhez, anélkül hogy ennek valódi oka tudatosulna. Később a ragadós élmény alapján maga is határozott, negatív véleményt alkothat a címkével rendelkező személyekről (Bem 1972). További torzításokat okozhat a társas kategorizáció és a külső csoport észlelt homogenitása, mely szerint, ha valaki belekerül egy kategóriába, hasonlatos lesz a többihez, aki szintén a kategória bélyegét viseli magán. Ilyenkor a külső csoportban az „ő" közötti különbség elhalványul, „ők” egységesebbnek látszanak, mint amilyenek valójában, egyediségük kifakul, felszívódik a szemlélő számára (Ottati et al. 2005, Smith et al. 2016).

A motivációs modellek a megbélyegzés célját, funkcióját vizsgálják egyén és közösség szempontjából. A pszichoanalitikus drive-elmélet szerint az egyén belső feszültségeit csökkentheti ismeretlen, vagy el nem ismert érzéseinek másokra vetítésével. Ezáltal a saját nehezen elfogadható tulajdonságait, érzéseit kívülre helyezheti, míg azok saját magában továbbra is rejtettek maradnak (Corrigan et al. 2005, Freud 1994, Sztancsik 2019). Az igazságos világba vetett hit szintén megerősítheti ezt a projekciós folyamatot: a jó emberekkel jó dolgok történnek, a rossz emberekkel rosszak, azokról „ők” tehetnek. Hasonló módon nem csak a szerencsétlenségeket háríthatja el önmagától ehhez hasonló módon a psziché, hanem valamennyi kellemetlen dolgot, ami az élettel jár: a mentális betegségek terhét, az öregkort és a vele járó szellemi, testi hanyatlást is (Lerner 1980, Ottati et al. 2005).

Önmagában az egyén motivációi és az ember kognitív-affektív jellemzői nem adnak kimerítő választ a megbélyegzések létezésére. A szociológiai modellek a diszkrimináció társadalmi és intézményes feltételeit és okait vizsgálják. Ide tartoznak a megtapasztalt stigmák mögött húzódó olyan rendszerszintü tényezők, mint pl. a jogrendszer, ami ha mostohán bánik egy csoporttal, az a társadalmi szokások légkörét is ennek megfelelően befolyásolja, legitim alapot 
nyújt a kirekesztéshez (Link és Phelan 2001, Sztancsik 2019). Corrigan et al. (2005) a társadalmi megkülönböztetés szerkezeti és szervezeti fajtáját különítik el. Előbbi esetén általában más a szándék és a hatás. Például a költséghatékonyság társadalmilag kívánatos, de az erre való törekvésnek - nem szándékosan - olyan hatása lehet, hogy az idősek és a mentális zavarral élők eleshetnek előnyöktől, amelyeket a „magasabb társadalmi hasznosságú” személyek megkapnak. A szervezeti diszkrimináció esetén nem más a szándék, mint ami a megkülönböztetés hatása: például, amikor egy bank maximális életkort határoz meg egy személyi kölcsön felvételekor a hitel kifutási idejére.

\section{A STIGMA HÁTRÁLTATÓ SZEREPE AZ IDÖSKORI MENTÁLIS BETEGSÉGEK PREVENCIÓJÁBAN}

A prevenciónak három szintjét különböztetjük meg. Bár számos hatékony eszköz áll rendelkezésünkre, az időskori mentális betegekkel kapcsolatos stigma mindhárom szinten nehezíti a megelőzést.

A primer prevenció a rizikótényezők kontrollálásával foglalkozik, célja a betegség előfordulásának, megjelenési valószínűségének csökkentése. Ennek fő eszköze az életmódbeli körülmények változtatása és az attitűdformálás (Pikó 2003). Az idősödéssel szembeni stigmával ezen a szinten számos tennivaló akad, hiszen aki nem azonosul korának kihívásaival (akár a stigma miatt), az a kedvező preventív gyakorlatokat sem fogja követni. Sok, a mentális egészséget veszélyeztető rizikófaktor visszavezethető életmódunkra, mint pl. a mozgásszegénység vagy az atomizált társadalom. Ezen tényezők számtalan aspektusa hat megbélyegzően az idősekre: kezdve a reklámok által sulykolt fiatalságkultusztól az emberi életet annak gazdasági értékével mérő társadalmi berendezkedésig. Az idősek ráadásul nap mint nap szembesülnek saját éltességükkel: a nyugdíj, az időskori kedvezmények, életbiztosítási ajánlatok mind emlékeztetik őket, hogy kronológiai életkoruknál fogva mások, mint a társadalom többsége (Widrick - Raskin 2010).

Az ageizmus a generációk közötti sztereotip gondolkodásra, elöítéletre, vagy diszkriminációra való hajlam, mely a társadalom valamennyi korcsoportját érinti, jóllehet, eltérő módon. Az ageizmus kialakulásáért felelős lehet a valóság torzítása, a tények mellőzése, vagy egyes elszigetelt esetek felnagyítása, általánosítása (Csepeli 1994, Kolos et al. 2020). Az uralkodó sztereotípiának köszönhetően a fiatalok és idősek közötti interakció korlátozott. A fiatalok egy része tart az idősekkel való kapcsolatfelvételtől és úgy gondolja, hogy az idősek elítélő véleménnyel vannak róluk. Ezzel szemben az idősek gyakran úgy vélik, a fiatalok nem is keresik szívesen az ő társaságukat (Kolos et al. 2020). Pedig a szociális kapcsolatok protektív tényezők lennének az időskori depresszióval és öngyilkossággal szemben (Blazer - Hybels 2005).

A testi betegségek csökkentésének is szerepe van a mentális betegségek megelőzésében. Túl az említett kapcsolaton a keringési betegségek és a depresszió előfordulása között, a testi betegséggel járó korlátozottság és kiszolgáltatottság is károsíthatja a mentális egészséget. A megelőzésben ezért előkelő helyet kell elfoglalnia a helyes táplálkozás és a testmozgás népszerüsítésének (Batízné Mikulán 2011, Laurin et al. 2001).

A szekunder prevenciót, mely a betegség minél korábbi felismerését célozza, szintén nehezíti a stigma. Idős korban a mentális betegségek diagnózisa rendszerint késik, melynek egyik fö 
oka az ún. „label avoidance” (bélyegelkerülés): az egyén kerüli azokat a helyzeteket, amelyeket stigmatizálónak él meg, így sokan nem is fordulnak orvoshoz tüneteikkel. A segítségkérést nehezíti az a tévhit is, miszerint az időskori szellemi leépülés elkerülhetetlen és kezelhetetlen. Mindemellett gyakran az orvosok is kevésbé hajlandók kimondani a demencia diagnózisát, mivel ők is erősen stigmatizálónak érzik azt (Benbow - Jolley 2012).

A prevenció harmadik szintjén a már fennálló betegség hosszú távú káros hatásainak csökkentése és a rehabilitáció áll. Annak ellenére, hogy például a demencia jelenleg nem gyógyítható, progressziójának lassítására ma már hatékony gyógyszeres kezelések érhetők el, és számos életmódbeli tényező jótékony hatását is leírták: ilyen a rendszeres testmozgás, a szellemi aktivitás és a társas interakciók (Batízné Mikulán 2011, Heyn et al. 2004). Ezzel szemben sajnos a hatékony kezelést sok esetben akadályozza a stigma: ha elmarad a diagnózis, elmarad a korai kezelésbe vétel is. Az orvos könnyebben lemond az idős betegről, ha tartja magát ahhoz a téves sztereotípián alapuló elképzeléshez, hogy a demencia és időskori hangulatzavar az öregség szükségszerü velejárója (Benbow - Jolley 2012).

Vajda Norbert és Heim Szilvia az Interprofesszionális Demencia Alapprogram (INDA) keretei között vizsgálták a hazai „kapu-őr” háziorvosok véleményét a demenciában szenvedő betegek kapcsán, akik „leggyakrabban azt gondolták [róluk], hogy magatehetetlen, nem gyógyítható, kilátástalan, szánalmas emberek. A saját érzéseik a betegséggel kapcsolatban a tehetetlenség, a bizonytalanság, a megrendülés és a sajnálat érzés voltak." (Heim 2015: 4)

Maga az Alzheimer-kór ritkán volt szem előtt a háziorvosok számára. A betegség gyanúját a korai fázisokban többnyire a hozzátartozók vetették fel. Az orvosok számára csak középsúlyos-súlyos esetekben merült csak fel a betegség gyanúja, minek oka szerintük a páciens hárításában, illetve a család bagatellizálásában keresendő. A hárítás a háziorvosokra is jellemző volt: kompetenciahiányra hivatkoztak, a problémával való szembenézést elodázták, illetve félmegoldásokkal operáltak (pl. értágító felírása). A betegek ritkán kaptak időben megfelelő szakorvosi ellátást, amire általában akkor került sor, amikor a család már nem tudta kezelni a demenciában szenvedő hozzátartozót (Heim 2015).

Összességében elmondható, hogy a stigma nemcsak azokat az időseket sújtja, akik már mentális betegségben szenvednek, de jelentősen nehezíti ezeknek a betegségeknek a megelőzését és az állapotjavulás elérését is. A stigmatizációcsökkentő programok így nem csak a betegeken segíthetnek, hanem maguknak a betegségeknek a megelőzéséhez és kedvező kimenetelü kezeléséhez is nagyban hozzájárulhatnak.

\section{A MENTÁLIS ZAVAROKKAL ÉLÖK MEGBÉLYEGZÉSÉNEK ÉS DISZKRIMINÁCIÓJÁNAK KUTATÁSA ÉS NEMZETI ANTISTIGMA PROGRAM (NAP) KIDOLGOZÁSA}

A mentális zavarokkal élőkkel szemben megnyilvánuló stigmatizáció jól ismert, általános jelenség (Moravcsik Alapítvány 2020), ami jelentős mértékben érinti az időskorú mentális zavarban szenvedő pácienseket is. A stigmatizáló gondolkodás, szemlélet, megnyilvánulás bár jellegzetes eltéréseket mutathat, nem korlátozódik egyes országokra, közösségekre. A stigma, legyen szó annak bármely altípusáról (pl. nyilvános stigma, önstigma, intézményi stigmatizáció), jelentős hatást gyakorol a pszichiátriai ellátás, gondozás, rehabilitáció sikerére és a 
mentális zavarokkal élők életminőségére (Semrau et al. 2015, Sztancsik 2018, Thornicroft et al. 2015). Nemzetközi szakirodalmi adatok alapján a mentális zavarral élők közel 50\%-a tart attól, hogy betegsége miatt igazságtalan bánásmódban lesz része. Közel egyharmaduk tapasztal mentális zavarával kapcsolatba hozható hátrányokat a munkavállalás területén, és csaknem minden ötödik beteg számol be nehézségekről a pénzintézetekkel, biztosítókkal való együttműködés terén.

Magyarországon eddig elsősorban helyi és a problémát főként a betegek szemszögéből közelítő, rehabilitációs folyamatba ágyazott antistigma programok születtek. Ezzel, a pszichiátriai szolgáltatások körén túl, néhány nonprofit szervezet is foglalkozik, például a NapraForgó Nonprofit Közhasznú Kft. rehabilitációs programot és a Lélekben Otthon Alapítvány „Vissza a Munkába” csoportot működtet (Baran 2019). Az időskori mentális betegségekhez kapcsolódóan ismeretterjesztő munkát végez, és támogató közösségek megteremtésén dolgozik az Alzheimer Café mozgalom is, ami a demenciával élők és családtagjaik destigmatizációjában és életminőségének javításában is fontos szerepet játszik (részletesebben lásd: Pék Győző et. al. [2021]: Támogató csoport demenciával élő családtagot gondozó hozzátartozók számára. Esély, 1: 37-48.).

A mentális zavarokkal kapcsolatos releváns és reális ismeretek átadása, ennek nyomán pedig az átlagpopuláció érzékenyítése mindezek ellenére Magyarországon továbbra is háttérben maradt. További hiányosság emellett a megfelelő mérőeszközök és ezzel összefüggésben a stigmatizáció elterjedtségére vonatkozó adatok hiánya is, melynek ismerete fontos alapot jelenthet egy átfogó antistigma stratégia és program kidolgozásához.

A mentális zavarokkal élőkkel szemben megnyilvánuló stigmatizáció hátrányos hatásainak csökkentése és objektív adatok alapján kidolgozásra kerülő antistigma program kidolgozása céljából a Moravcsik Alapítvány és a Semmelweis Egyetem Pszichiátriai és Pszichoterápiás Klinika képviselői 2019-ben részt vettek a Global Anti-Stigma Alliance (GASA) nemzetközi konferenciáján Prágában. A konferencián és ezt követően itthon történt egyeztetések vezettek el 2020-ban, Simon Lajos vezetésével a Magyar Antistigma Munkacsoport megalapításához. A munkacsoport bár rövid történetre tekint vissza, kezdettől széleskörű szakmai együttmüködésre törekszik a stigmatizáció mérséklése és a pszichiátriai betegek hatékonyabb társadalmi beilleszkedésének segítése érdekében.

A munkacsoport az említett hiányosságok kiküszöbölése, valamint a lokális programok hatókörének kiterjesztése mellett köteleződött el. Ennek érdekében egy több lépcsős megvalósítási tervet dolgoztak ki, mely a megfelelö, nemzetközi gyakorlatban is elterjedt, validált mérőeszközök biztosításától egy komplex, a magyar viszonyokhoz igazodó, a nemzetközi ajánlásokkal is összhangban álló antistigma program kifejlesztéséig és elindításáig terjed (Sztancsik - Szemán-Nagy 2020b).

Jelenleg a mérőeszközök validálása és a széleskörű adatgyűjtés folyik, melynek eredményeként pár hónap alatt már több mint 1000 személy töltötte ki az anonim kérdőíveket. Ez az anonim online kérdőív megtalálható a http://vikote.hu/mentalis-betegsegekkel-szembeniattitud-vizsgalat/ weboldalon. 
A Nemzeti Antistigma Program (NAP) célja elérni mindhárom korábban fent említett stigma típus hátrányos hatásainak csökkentését, mérhető módon egyéni és társadalmi szinten egyaránt. A program négy alapvető területre épül:

1. Edukáció - a betegséggel kapcsolatos hiedelmek változtatása, a betegségre vonatkozó ismeretek növelése (informális és non-formális tanulási módokon is) az érintett személyeknél és családjuknál, a reintegrációban érintett munkahelyi közösségekben, a fiatalok között, az iskolákban és a széles nyilvánosságban.

2. A személyes megtapasztalás - lehetővé tétele a pszichoszociális fogyatékossággal élők és a mentálisan egészséges személyek között (közös munka, közös alkotási tevékenység, „Élő könyvtár" programok, önkéntes munka az érintettekkel stb.)

3. Láthatóvá tétel, megismerés - a mentális zavarral élő személyek értékteremto, alkotó képességének és alkotásaiknak a bemutatása a szűkebb szakmai és a széles nagyközönség előtt (tehetségkutatás, tehetséggondozás, müvészi tevékenység).

4. Intézményi destigmatizáció - a szükséges és megfelelő színtü állami, kormányzati támogatás kialakítása és az igénybevételnek jogszabályban történő rögzítése.

Az említett program létrehozása képezi a munkacsoport tevékenységének fó fókuszát, melyet a munkacsoport tagjai a mentális zavarral élök stigmatizációval összefüggő egyéni terheinek csökkentésében és a következményes, az egészségügyi és szociális rendszerre, társadalomra is kivetülö többletköltségek mérséklésében egyaránt fontosnak tartanak.

A mentális, azaz pszichiátriai betegségekkel kapcsolatos széleskörü tájékoztatás és elérhető, stigmatizációtól mentes szolgáltatások létrehozása és megerősítése az időskorú emberek tekintetében is nagyon fontos feladat. A szociális alapellátások körébe tartozik nem csak az időskorúak gondozása, de a közösségi pszichiátriai ellátás is, mely már müködik hazánkban még ha sok helyen forrás- és szakemberhiánnyal is küzd (Bódy 2012, Haiman 2012, Rostás 2012). A szerzőket is magában foglaló kutatócsoportunk célkitüzései az általános tájékoztatás mellett csak a szociális és pszichiátriai ellátás szereplőinek, a társszakmák szakembereinek és a döntéshozóknak a képzésén, érzékenyítésén keresztül valósítható meg.

\section{IRODALOM}

Andreas, S. - Schulz, H. - Volkert, J. - Dehoust, M. - Sehner, S. - Suling, A. - Ausín, B. Canuto, A. - Crawford, M. - Da Ronch, C. - Grassi, L. - Hershkovitz, Y. - Muñoz, M. Quirk, A. - Rotenstein, O. - Santos-Olmo, A. B. - Shalev, A. - Streh(le, J. - Weber, K. Wegscheider, K. - Wittchen HU. - Härter, M. (2017): Prevalence of mental disorders in elderly people: the European MentDis_ICF65+ study. The British journal of psychiatry: the journal of mental science, 210(2): 125-131. DOI: 10.1192/bjp.bp.115.180463

Baran B. (2019): A pszichiátriai beteg, mint munkavállaló jogai, jogérvényesítése, elhelyezkedésének feltételei, a diszkrimináció megszüntetése. NNK Foglalkozás-egészségügyi Fórum, Budapest, 2019.09.11. https://www.nnk.gov.hu/attachments/article/285/02_Dr_Baran_Brigitta_forum-2019-09-11.pdf (Utolsó letöltés: 2021.01.18.)

Batízné Mikulán R. (2011): Az életmód szerepe az időskori kognitív zavarok prevenciójában és rehabilitációjában. Rekreáció, 1(1): 27-30. DOI: 10.21486/recreation.2011.1.1.4 
Bem, D. J. (1972): Self-Perception Theory. In: L. Berkowitz (ed.), Advances in Experimental Social Psychology. Volume six. Cambridge: Academic Press, 1-62. DOI: 10.1016/S00652601(08)60024-6

Benbow, S. M. - Jolley, D. (2012): Dementia: stigma and its effects. Neurodegenerative Disease Management, 2(2): 165-172. DOI: 10.2217/nmt.12.7

Blazer, D. G. - Hybels, C. F. (2005): Origins of depression in later life. Psychological Medicine, 35(9): 1241-1252. DOI: 10.1017/s0033291705004411

Bódy É. (2012): A közösségi ellátás keretei a közösségi ellátás talaján. In: Váradi E. (szerk.): Pszichiátriai gondozási kézikönyv. Budapest: Oriold és Társai Kiadó. 261-270.

Combs, A. W. - Snygg, D. (1959): Individual behavior. Revised edition. New York: Harper \& Row.

Corrigan, P. W. - Watson A. C. (2002): The paradox of self-stigma and mental illness. Clinical Psychology: Science and Practice, 9(1): 35-53. DOI: 10.1093/clipsy/9.1.35

Corrigan, P. W. - Kerr, A. - Knudsen, L. (2005): The stigma of mental illness: explanatory models and methods for change. Applied and Preventive Psychology, 11: 179-190. DOI: 10.1016/j.appsy.2005.07.001

Csepeli Gy. (1994): Bevezetés a szociálpszichológiába. Budapest: Tankönyvkiadó.

Erikson, E. H. (2002): Gyermekkor és társadalom. Budapest: Osiris.

Eurostat (2019): Disability statistics - elderly needs for help or assistance. Eurostat statistics explained. https://ec.europa.eu/eurostat/statistics-explained/index.php?title=Disability_ statistics_-_elderly_needs_for_help_or_assistance (Utolsó letöltés: 2021.01.18.)

Eurostat (2020): Population structure and ageing. Eurostat statistics explained. https://ec. europa.eu/eurostat/statistics-explained/index.php?title=Population_structure_and_ ageing (Utolsó letöltés: 2021.01.18.)

Frable, D. E. - Platt, L. - Hoey, S. (1998): Concealable stigmas and positive self-perceptions: feeling better around similar others. Journal of personality and social psychology, 74(4): 909-922. DOI: 10.1037//0022-3514.74.4.909

Freud, A. (1994): Az én és az elháritó mechanizmusok. Budapest: Animula.

Gazdag G. - Sebestyén, G. (2005): Gerontopszichiátriai problémák megjelenése a konzultációs pszichiátriai gyakorlatban. Neuropsychopharmacologia Hungarica, 7(3): 140-145.

Goffman, E. (1963): Stigma: Notes on a spoiled identity. New York: Simon \& Schuster.

Goldberg, D. P. - Bridges, K. (1988): Somatic presentations of psychiatric illness in primary care setting. Journal of psychosomatic research, 32(2): 137-144. DOI: 10.1016/00223999(88)90048-7

Haiman É. (2012): Az önkormányzatok és az állam szerepe és feladatai a pszichiátriai és a szenvedélybetegek és családtagjaik segítésében. In: Váradi E. (szerk.): Pszichiátriai gondozási kézikönyv. Budapest: Oriold és Társai Kiadó. 253-260.

Hatzenbuehler, M. L. (2009): How does sexual minority stigma "get under the skin"? A psychological mediation framework. Psychological bulletin, 135(5): 707-730. DOI: 10.1037/ a0016441 
Hatzenbuehler, M. L. (2016): Structural stigma: Research evidence and implications for psychological science. The American psychologist, 71(8): 742-751. DOI: 10.1037/ amp0000068

Hatzenbuehler, M. L. - Nolen-Hoeksema, S. - Dovidio, J. (2009): How does stigma "get under the skin"?: the mediating role of emotion regulation. Psychological science, 20(10): 12821289. DOI: $10.1111 /$ j.1467-9280.2009.02441.x

Heim Sz. (2015): A háziorvosok szerepe és lehetőségei az időskori demenciák ellátásában. Kutatásvezető: Vajda N. Készült az Interprofesszionális Demencia Alapprogram keretében. TÁMOP 5.4.12-14/1-2015-0007. https://www.inda.info.hu/uploads/dokumentumok/ Haziorvosok_szerepe_web.pdf Letöltés: 2021.04.29.

Heyn, P. - Abreu, B. C. - Ottenbacher, K. J. (2004): The effects of exercise training on elderly persons with cognitive impairment and dementia: A meta-analysis. Archives of Physical Medicine and Rehabilitation, 85(10): 1694-1704. DOI: 10.1016/j.apmr.2004.03.019

Jones, E. E. - Farina, A. - Hastorf, A. H. - Markus, H. - Miller, D. T. - Scott, R. A. (1984): Social Stigma: The Psychology of Marked Relationships. New York: W. H. Freeman.

Kolos K. - Kenesei Zs. - Kiss K. - Kovács E. - Michalkó G. - Pinke-Sziva I. (2020): Az ageizmus kialakulására ható tényezők magyar fiatalok és idősek körében. Demográfia, 63(1): 5-34. DOI: 10.21543/DEM.63.1.1

Központi Statisztikai Hivatal (2020): Népesség és népmozgalom, 2020. Budapest.

Laurin, D. - Verreault, R. - Lindsay, J. - MacPherson, K. - Rockwood, K. (2001): Physical Activity and Risk of Cognitive Impairment and Dementia in Elderly Persons. Archives of Neurology, 58(3): 498-504. DOI: 10.1001/archneur.58.3.498

Lerner, M. J. (1980): The Belief in a Just World. A Fundamental Delusion. New York: Springer. https://doi.org/10.1007/978-1-4899-0448-5

Monostori J. - Gresits G. (2018): Idősödés. In Monostori J. - Öri P. - Spéder Zs. (szerk.) Demográfiai portré 2018. Budapest: KSH NKI, 127-145.

Moravcsik Alapítvány (2020): Antistigma kérdöív. https://moravcsikalapitvany.hu/antistigmakerdoiv/

Ólafsdóttir, M. - Marcusson, J. - Skoog, I. (2001): Mental disorders among elderly people in primary care: the Linköping study. Acta psychiatrica Scandinavica, 104(1): 12-18. DOI: 10.1034/j.1600-0447.2001.104001012.x

Ottati, V. - Bodenhausen, G. V. - Newman, L. S. (2005): Social Psychological Models of Mental Illness Stigma. In P. W. Corrigan (ed.): On the stigma of mental illness: Practical strategies for research and social change. Washington: American Psychological Association, 99-128. DOI: $10.1037 / 10887-004$

Pachankis, J. E. - Hatzenbuehler, M. L. - Wang, K. - Burton, C. L. - Crawford, F. W. - Phelan, J. C. - Link, B. G. (2018): The Burden of Stigma on Health and Well-Being: A Taxonomy of Concealment, Course, Disruptiveness, Aesthetics, Origin, and Peril Across 93 Stigmas. Personality \& social psychology bulletin, 44(4): 451-474. DOI: $10.1177 / 0146167217741313$ 
Pethő B. (1989): Gerontopsychiatria. In Pethő B. (szerk.): Részletes psychiatria. Organikus betegségek. Funkcionális betegségek és zavarok. Budapest: Magyar Pszichiátriai Társaság, 475642.

Pikó B. (2003): Magatartástudomány és prevenció: a preventív magatartásorvoslás jelentősége. Magyar Tudomány, 48(11): 1381-1390.

Rostás A. (2012): A pszichiátriai ellátás szereplői. In: Váradi E. (szerk.): Pszichiátriai gondozási kézikönyv. Budapest: Oriold és Társai Kiadó. 241-252.

Semrau, M. - Evans-Lacko, S. - Koschorke, M. - Ashenafi, L. - Thornicroft, G. (2015): Stigma and discrimination related to mental illness in low- and middle-income countries. Epidemiology and psychiatric sciences, 24(5): 382-394. DOI: 10.1017/S2045796015000359

Semsei I. (2014): Gerontológia. Debrecen: Debreceni Egyetem Egészségügyi Kar. https://regi. tankonyvtar.hu/hu/tartalom/tamop412A/2010_0020_gerontologia_magyar/irodalomjegyzk.html (Utolsó letöltés: 2021. 01. 18.)

Smith, E. R. - Mackie, D. M. - Claypool, H. M. (2016): Szociálpszichológia. Budapest: ELTE Eötvös.

Sztancsik V. (2018): A skizofréniához füződő megbélyegzésröl. Psychiatria Hungarica, 33(2): 93-105.

Sztancsik V. (2019): A mentális betegség bélyege. Budapest: Oriold és Társai.

Sztancsik V. - Szemán-Nagy, A. (2020a): The Stigma of Mental Illness - Conceptions and Phenomena. In Szemán-Nagy A. - Körmendi A. (szerk.) Bonding and Separation - Current Problems in Clinical Psychology. Debrecen: Debrecen University Press, 110-119.

Sztancsik V. - Szemán-Nagy A. (2020b): Stigma Impairment and Options for Change. In Szemán-Nagy A. - Körmendi A. (szerk.) Bonding and Separation - Current Problems in Clinical Psychology. Debrecen: Debrecen University Press, 120-128.

Tariska P. (2002): Kortünet vagy kórtünet? Mentális zavarok az idöskorban. Budapest: Medicina.

Thornicroft, G. - Mehta, N. - Clement, S. - Evans-Lacko, S. - Doherty, M. - Rose, D. Koschorke, M. - Shidhaye, R. - O'Reilly, C. - Henderson, C. (2015): Evidence for effective interventions to reduce mental-health-related stigma and discrimination. Lancet (London, England), 387(10023): 1123-1132. DOI: 10.1016/S0140-6736(15)00298-6

Tringer L. (2010): A pszichiátria tankönyve. Budapest: Semmelweis Kiadó.

Vörös V. (2010): Az öngyilkos viselkedés komplex stressz-diatézis szemlélete. Doktori (PhD) értekezés. Pécs: Pécsi Tudományegyetem. https://aok.pte.hu/docs/phd/file/dolgozatok/2010/ Voros_Viktor_magyar_tezisfuzet.pdf (Utolsó letöltés: 2021.01.18.)

Weiller, E. - Bisserbe, J. C. - Maier, W. - Lecrubier, Y. (1998): Prevalence and recognition of anxiety syndromes in five European primary care settings. A report from the WHO study on Psychological Problems in General Health Care. The British journal of psychiatry. Supplement, (34): 18-23. https://doi.org/10.1192/S0007125000293471

Weiner, B. - Perry, R. P. - Magnusson, J. (1988): An attributional analysis of reactions to stigmas. Journal of Personality and Social Psychology, 55(5): 738-748. DOI: 10.1037/0022-3514. 55.5.738 
Weöres S. (1975): Egybegyüjtött írások I-III. Budapest: Magvető.

Widrick, R. M. - Raskin, J. D. (2010): Age-related stigma and the golden section hypothesis. Aging \& Mental Health, 14(4): 375-385. DOI: 10.1080/13607860903167846

Williams, J. W., Jr. - Kerber, C. A. - Mulrow, C. D. - Medina, A. - Aguilar, C. (1995): Depressive disorders in primary care: prevalence, functional disability, and identification. Journal of general internal medicine, 10(1): 7-12. DOI: 10.1007/BF02599568

World Health Organization (2020): The top 10 causes of death, 2019. Fact Sheets. https://www. who.int/news-room/fact-sheets/detail/the-top-10-causes-of-death (Utolsó letöltés: 2021. 01.18.)

Yanos, P. T. - Roe, D. - Lysaker, P. H. (2011): Narrative enhancement and cognitive therapy: A new group-based treatment for internalized stigma among persons with severe mental illness. International Journal of Group Psychotherapy, 61(4): 577-595. DOI: 10.1521/ ijgp.2011.61.4.576

Zhang, Y. - Chen, Y. - Ma, L. (2018): Depression and cardiovascular disease in elderly: Current understanding. Journal of Clinical Neuroscience, 47: 1-5. DOI: 10.1016/j.jocn.2017.09.022 